\title{
Detection of virulence genes and antimicrobial resistance profiles of Escherichia coli isolates from raw milk and artisanal cheese in Southern Brazil
}

\author{
Detecção de genes de virulência e perfis de resistência \\ antimicrobiana de Escherichia coli isoladas de leite cru e queijo \\ artesanal no Sul do Brasil
}

\author{
Leandro Parussolo ${ }^{1 *}$; Ricardo Antônio Pilegi Sfaciotte ${ }^{2}$; Karine Andrezza Dalmina \\ Fernanda Danielle Melo ${ }^{4}$; Ubirajara Maciel da Costa ${ }^{5}$; Sandra Maria Ferraz ${ }^{5}$
}

\begin{abstract}
The serrano artisanal cheese is a typical product from South region of Brazil, which is produced by skilled cheesemakers using raw milk. The contamination of this food by Escherichia coli has a great impact on public health, since it could threat the consumers' health. The study evaluated the presence of virulence genes, antimicrobial susceptibility profiles and bofilm-production ability of Escherichia coli isolates obtained from raw milk and artisanal cheese produced in Southern Brazil. A total of 117 isolates of E. coli were characterized by multiplex PCR to detect the following virulence genes: eae for enteropatogenic E. coli (EPEC), lt and st for enterotoxigenic E. coli (ETEC), stx for shiga toxinproducing E. coli (STEC), stx and eae for enterohemorrhagic E. coli (EHEC), ipaH for enteroinvasive $E$. coli (EIEC) and aggR for enteroaggregative E. coli (EAEC). In addition, antimicrobial susceptibility profile to 22 antimicrobial agents was also performed by disk diffusion method, and we searched for extended-spectrum beta-lactamases (ESBL) and/or carbapenemase-producing isolates. Isolates that were positive for ESBL and carbapenemase were further investigated for the presence of the genes: $b a_{\text {TEM' }}$, $b l a_{\mathrm{SHV},} b l a_{\mathrm{OXA}}, b l a_{\mathrm{CTX}-\mathrm{M}}$, for ESBL and $b l a_{\mathrm{OXA}-48}$ for carbapenemase. Further, isolates had their ability to form biofilms investigated by the red Congo agar method. Virulence genes of $E$. coli were identified in $21.37 \%$ of the tested isolates, which were classified as EPEC (the most prevalent pathotype) and ETEC or EAEC. Ten $(8.55 \%)$ of the total studied E. coli isolates revealed a multidrug-resistant profile, since they were resistant to three or more antimicrobial classes; whereas four isolates $(3.42 \%)$ were classified as ESBL-producers and showed the presence of $b l a_{\text {TEM }}$ gene. None of the isolates exhibited carbapenemase activity nor did they carry carbapenemase genes. From the total of $E$. coli isolates, 79 $(67.52 \%)$ were considered potential biofilm producers. These results address a serious public health issue, since artisanal cheeses pose a risk to consumers' health, since may be sources of dissemination of diarrheogenic $E$. coli, that can cause from subclinical to severe and fatal infections in children and adults, and also emphasize the need to improve adaptations/adjustments in the manufacturing processes
\end{abstract}

1 Prof. Dr., Instituto Federal de Santa Catarina, IFSC, Câmpus Florianópolis, Florianópolis, SC, Brasil. E-mail: leandro.parussolo@, ifsc.edu.br

2 Discente, Curso de Doutorado do Programa de Pós-Graduação em Ciência Animal, Universidade do Estado de Santa Catarina, UDESC, Centro de Ciências Agroveterinárias, Câmpus Lages, Lages, SC, Brasil. E-mail: sfaciotti@hotmail.com

3 M.e, Ciência Animal, UDESC, Centro de Ciências Agroveterinárias, Câmpus Lages, Lages, SC, Brasil. E-mail: karine_dalmina@ hotmail.com

4 Dra ${ }^{\mathrm{a}}$, Ciência Animal, UDESC, Centro de Ciências Agroveterinárias, Câmpus Lages, Lages, SC, Brasil. E-mail: fernandamelovet@ gmail.com

5 Profs. Drs., UDESC, Centro de Ciências Agroveterinárias, Câmpus Lages, Lages, SC, Brasil. E-mail: ubirajara.costa@udesc.br; sandra.ferraz@udesc.br

* Author for correspondence 
of these products.

Key words: Diarrheagenic E. coli. Multi-drug resistance. ESBL. Biofilm.

\section{Resumo}

O queijo artesanal serrano é um produto típico da região sul do Brasil e se caracteriza por ser produzido a partir de leite cru. A contaminação desse alimento por Escherichia coli assume grande relevância para a saúde pública, pois oferece risco a saúde dos consumidores. Esse estudo avaliou a presença de genes de virulência, os perfis de susceptibilidade antimicrobiana e a capacidade de produção de biofilme de isolados de E. coli obtidos a partir de leite cru e queijo artesanal produzido no Sul do Brasil. Um total de 117 isolados de E. coli foram caracterizados por multiplex PCR para detecção dos seguintes genes de virulência: eae para $E$. coli enteropatogênica (EPEC), lt e st para $E$. coli enterotoxigênica (ETEC), $s t x$ para $E$. coli produtora da toxina shiga (STEC), stx e eae para E. coli enterohemorrágica (EHEC), $i p a H$ para E. coli enteroinvasiva (EIEC) e aggR para E. coli enteroagregativa (EAEC). Adicionalmente, o perfil de susceptibilidade antimicrobiana a 22 agentes antimicrobianos foi determinado pelo método de disco difusão e a busca de isolados produtores de beta-lactamases de espectro estendido (ESBL) e carbapenemase foram realizadas. Os isolados positivos para ESBL e carbapenemase foram investigados quanto a presença dos genes: $b l a_{\mathrm{TEM}}, b l a_{\mathrm{SHV}}, b l a_{\mathrm{OXA}}, b l a_{\mathrm{CTX}-\mathrm{M}}$ para ESBL e $b l a_{\mathrm{OXA}-48}$ para carbapenemase. Além disso, a potencial capacidade dos isolados de E. coli em produzir biofilme foi determinada pela técnica do ágar vermelho Congo. Os genes de virulência de $E$. coli foram identificados em 21,37\% dos isolados testados, que foram classificados como EPEC (patótipo mais prevalente), ETEC ou EAEC. Dez $(8,55 \%)$ isolados de E. coli apresentaram perfil de multirresistência, pois foram resistentes a três ou mais classes de antimicrobianos; enquanto que quatro isolados $(3,42 \%)$ foram classificados como produtores de ESBL, sendo identificado o gene $b l a_{\mathrm{TEM}}$. Nenhum isolado foi classificado como produtor de carbapenemase. Do total de isolados de E. coli, $79(67,52 \%)$ foram considerados potenciais produtores de biofilme. Esses resultados alertam para um problema de saúde pública, porque o queijo artesanal pode ser fonte de disseminação de E. coli diarreiogênica, que pode causar infecções subclínicas ou severas e fatais em crianças e adultos. Esses resultados também evidenciam a necessidade de melhorias e adequações nos processos de fabricação desse produto.

Palavras-chave: E. coli diarreiogênica. Multirresistência. ESBL. Biofilme.

\section{Introduction}

The serrano artisanal cheese is a traditional product from the highland fields in the South region of Brazil. The production is characterized by the use of raw milk from dairy cattle that grazed on natural pastures of its own rural property (PEREIRA et al., 2014). Besides the possibility of raw milk to contain potentially harmful microorganisms to human health (NOBILI et al., 2016; NTULI et al., 2016; RANJBAR et al., 2018), serrano artisanal cheese is often produced under poorly hygienic conditions, posing at risk the health of consumers (MELO et al., 2013; PONTAROLO et al., 2017; SOUZA et al., 2003; ZAFFARI et al., 2007). Previous studies showed Escherichia coli is one of the major contaminants found in serrano artisanal cheese, produced in the Serrana region of Santa Catarina state, with a contamination rate superior to $45 \%$ (MELO et al., 2013; PONTAROLO et al., 2017). Although several strains of $E$. coli are considered commensal, there are pathogenic strains that cause serious gastrointestinal infections in humans and are called diarrheagenic E. coli (YANG; WANG, 2014).

The diarrheagenic strains of $E$. coli exhibit have specific virulence factors that ease their interaction with the host. For that reason, it is important to distinguish pathogenic E. coli types, such as: enteropatogenic E. coli (EPEC), shiga toxin-producing $E$. coli (STEC), enterohemorrhagic E. coli (EHEC), enterotoxigenic E. coli (ETEC), enteroinvasive $E$. coli (EIEC) and enteroaggregative E. coli (EAEC), from those nonpathogenic 
(GYLES; FAIRBROTHER, 2010; YANG; WANG, 2014). This distinction of E. coli strains has not only epidemiological implications, but also clinical consequences to prevent and control of diarrheal diseases. Detection of virulence factors is a way to identify the different types of this pathogen, since they are considered exclusive to each pathotype (GIRÃO et al., 2006).

Eight diarrheagenic E. coli (DEC) groups are known: shiga toxin-producing E. coli (STEC), which includes the subgroup enterohemorrhagic $E$. coli (EHEC); typical and atypical enteropathogenic E. coli (EPECt and EPECa); enterotoxigenic E. coli (ETEC); enteroinvasive E. coli (EIEC); enteroaggregative E. coli (EAEC); diffusely adherent E. coli (DAEC); and adherent invasive E. coli (AIEC). Enteroaggregative hemorrhagic E. coli (EAHEC) O104:H4 is an emerging E. coli pathotype associated with an outbreak that occurred in Germany in May 2011. The genes used for genetic characterization of these groups are $s t x 1$ and stx2 (STEC); stx1, stx2, and eae (EHEC); eae (EPECa); eae and $b f p$ (EPECt); enterotoxin genes LT and ST and colonization factors (ETEC); $i p a H$ and ial (EIEC); and $a g g R$, aap, and $A A$ probe (EAEC) (CROXEN et al., 2013). Genes for the genetic characterization of AIEC have not yet been characterized and there is no agreement among authors for the genetic characterization of DAEC (NATARO; KAPER, 1998; CROXEN et al., 2013). EAHEC O104:H4 is an enteroaggregative E. coli with the stx2a encoding gene (BEUTIN; MARTIN, 2012).

Another factor that can contribute to virulence is the ability of different microorganisms to form biofilms (KRAGH et al., 2016). Several studies have recognized the potential of $E$. coli to form biofilms, which represents an important issue not only for the treatment of infections caused by this pathogen but also for food processing environments (CULLER et al., 2014; PONNUSAMY et al., 2012; SILAGYI et al., 2009).
Not only the identification of virulence factors in E. coli, but also the investigation of antimicrobial susceptibility profile, are of utmost importance, since these microorganisms are often involved in serious human infections (SLAMA et al., 2010) and, bacterial dissemination is considered highly associated with processing production, transformation, manufacturing and trade of food (KIRBIS; KRIZMAN, 2015). Studies worldwide have demonstrated serious concern about the alarming antimicrobial resistance index, and the number of multi-drug resistant $E$. coli strains isolated from raw and pasteurized milk (NTULI et al., 2016), dairy products (GUILLÉN et al., 2014; NOBILI et al., 2016) and other types of food (GÓMEZALDAPA et al., 2016; WANG et al., 2017). One of the major resistance mechanisms developed by $E$. coli to adapt to antibiotic is the hydrolysis of the $\beta$-lactam ring through enzymes, defined as extended-spectrum beta-lactamases (ESBL), that confer resistance to antimicrobials from $\beta$-lactam class, including penicillins, cephalosporins and monobactams (ECDC, 2013; PFEIFER et al., 2010). However, these enzymes are not able to hydrolyse cephamycins and carbapenems, and could be inactivated by the action of beta-lactamase inhibitors (clavulanic acid, sulbactam and tazobactam) (LEE et al., 2012; PATERSON; BONOMO, 2005).

The ESBLs are classified into three major distinct structural and evolutionary families such as TEM, SHV and CTX-M (BUSH; JACOBY, 2010). Most genes encoding this type of antimicrobial resistance are located in conjugative plasmids or integron systems, and could be exchanged readily between enterobacteria species, facilitating their dissemination (CARATTOLI, 2013; WOODFORD et al., 2011). Current studies have reported the presence of ESBL producing $E$. coli in food, such as meat, milk and different types of cheese (GUNDOGAN; AVCI, 2013; SU et al., 2016; TEKINER; OZPINAR, 2016; VRABEC et al., 2015). Once beta-lactam resistant $E$. coli strains have become a global emerging problem in the last few years, carbapenems have been one of 
the main therapy options against human infections, including those caused by ESBL-producing bacteria (GENC et al., 2016; SPELLBERG et al., 2011). However, there are already reports of carbapenem resistance in isolates of clinical samples due to occurrence of enzymes named as carbapenemases (THOMSON, 2010).Although rare, some studies have isolated enterobacteria producing carbapenemase from foods such as seafood and vegetables (SINGH et al., 2016; ZURFLUH et al., 2015). Several types of carbapenemases were already described among Enterobacteriaceae, such as Klebsiella pneumoniae carbapenemase (KPC); zinc cofactor dependent carbapenemases known as metallo-beta-lactamases (MBL); oxacilinases (OXAs) (NORDMANN et al., 2011; TZOUVELEKIS et al., 2012); and cephalosporinases (AmpC) associated with the loss of porin (NORDMANN et al., 2012). The objective of this study was to evaluate the presence of virulence genes, antimicrobial susceptibility profiles and bifilm-production ability in $E$. coli isolates obtained from raw milk and artisanal cheese produced in Southern Brazil.

\section{Material and Methods}

\section{Bacterial isolates}

A total of 117 strains of Escherichia coli isolated from raw milk $(\mathrm{n}=8)$ and serrano artisanal cheese $(n=109)$ were evaluated. These isolates were obtained from previous studies carried out by our research group (MELO et al., 2013; PONTAROLO et al., 2017; DALMINA, 2018) at the Centro de Diagnóstico Microbiológico Animal (CEDIMA) at Universidade do Estado de Santa Catarina (UDESC), in cooperation with serrano artisanal cheese producers from Santa Catarina, South region of Brazil.

\section{Bacterial DNA extraction}

DNA extraction of isolates and reference strains (to assure quality control) was performed according to protocol described by Doyle and Doyle (1987) with some modifications. Bacterial isolates were cultivated in Brain Heart Infusion broth (BD Difco, USA) at $37^{\circ} \mathrm{C}$ for $24 \mathrm{~h}$, and consequently stored at $-20^{\circ} \mathrm{C}$. An aliquot of $200 \mu \mathrm{L}$ of each bacterial inoculum was transferred to a sterile microtube, and $500 \mu 1$ of chloroform: isoamyl alcohol (24:1) were added. The microtubes were placed in a waterbath at $56^{\circ} \mathrm{C}$ for $30 \mathrm{~min}$. After incubation period, microtubes were centrifuged for $10 \mathrm{~min}$ at 12,000 $\mathrm{rpm}$. The supernatant of each sample was transferred to another sterile microtube, and supplemented with $600 \mu \mathrm{L}$ of $70 \%$ alcohol. The samples were further centrifuged for $20 \mathrm{~min}$ at 13,500 rpm. Then, supernatant was discarded by inversion and the pellet was dried off at room temperature. Finally, DNA samples were resuspended in $200 \mu \mathrm{L}$ of sterile Milli-Q water.

\section{Detection of virulence genes}

Detection of $E$. coli virulence genes was performed through an adapted Multiplex PCR based on protocols described by Toma et al. (2003) and López-Saucedo et al. (2003), using the primers listed in table 1. PCR amplifications were conducted in a $25 \mu \mathrm{L}$ final volume containing PCR buffer (Tris- $\mathrm{HCl}-20 \mathrm{mM}, \mathrm{KCl}-50 \mathrm{mM}$ ), $\mathrm{MgCl}_{2}(2 \mathrm{mM})$, dNTP (200mM of each), Taq DNA polymerase $(0.5 \mathrm{U})$, primers ( $4 \mathrm{pmol}$ of each) and $2 \mu 1$ (15-60ng) bacterial DNA. All reagents were purchased from Invitrogen ${ }^{\circledR}$ (Carlsbad, USA) and reactions were carried out in Thermal Cycler Applied Biosystem (model MJ96, Thermo Fisher, USA). The PCR program was carried as follows: initial denaturation at $95^{\circ} \mathrm{C}$ for $5 \mathrm{~min}, 40$ cycles of denaturation at $95^{\circ} \mathrm{C}$ for $45 \mathrm{~s}$, annealing at $50{ }^{\circ} \mathrm{C}$ for $45 \mathrm{~s}$, extension at $72{ }^{\circ} \mathrm{C}$ for $45 \mathrm{~s}$, and final extension at $72{ }^{\circ} \mathrm{C}$ for $10 \mathrm{~min}$. Amplification products were analyzed by electrophoresis $(100 \mathrm{~V}, 300 \mathrm{~mA})$ for $1 \mathrm{~h}$ using $2 \%$ agarose gel. PCR products were stained with GelRed ${ }^{\mathrm{TM}}$ and visualized on transilluminator (Kasvi, model K33-312, Brazil). The reference 
strains Escherichia coli INCQS 00170 (ATCC 43893) - EIEC; Escherichia coli INCQS 00171 (ATCC 43895) - EHEC; Escherichia coli INCQS 00180 (CDC O111ab) - EPEC (Fundação Oswaldo Cruz - Fiocruz); Escherichia coli ATCC 35401
- ETEC; Escherichia coli 3929 - L0815 - EAEC (Instituto Adolfo Lutz) were used as positive controls to assure quality control of the assays. Escherichia coli ATCC 25922 reference strain was used as a negative control.

Table 1. List of primers used in Multiplex PCR for detection of virulence genes in E. coli isolates.

\begin{tabular}{|c|c|c|c|c|c|}
\hline $\begin{array}{c}\text { E. coli } \\
\text { (pathotype) }\end{array}$ & Gene & Primer & $\begin{array}{l}\text { Sequence of oligonucleotides } \\
(5,-3 \text { ') }\end{array}$ & $\begin{array}{l}\text { Size of am- } \\
\text { plicon (bp) }\end{array}$ & Described by: \\
\hline $\begin{array}{l}\text { EPEC and } \\
\text { EHEC* }\end{array}$ & eae & $\begin{array}{l}S K 1 \\
S K 2\end{array}$ & $\begin{array}{l}\text { CCCGAATTCGGCACAAGCATAAGC } \\
\text { CCCGGATCCGTCTCGCCAGTATTCG }\end{array}$ & 881 & $\begin{array}{l}\text { Oswald et al. } \\
\qquad(2000)\end{array}$ \\
\hline $\begin{array}{l}\text { STEC and } \\
\text { EHEC* }\end{array}$ & stx & $\begin{array}{l}\text { Vtcom- } u \\
\text { Vtcom-d }\end{array}$ & $\begin{array}{l}\text { GAGCGAAATAATTTATATGTG } \\
\text { TGATGATGGCAATTCAGTAT }\end{array}$ & 518 & $\begin{array}{l}\text { Yamasaki et al. } \\
\text { (1996) }\end{array}$ \\
\hline \multirow[b]{2}{*}{ ETEC } & $s t$ & $\begin{array}{l}s t-F \\
s t-R\end{array}$ & $\begin{array}{l}\text { ATTTTTCTTTCTGTATTGTCTT } \\
\text { CACCCGGTACARGCAGGATT }\end{array}$ & 190 & \multirow{2}{*}{$\begin{array}{l}\text { López-Saucedo } \\
\text { et al. (2003) }\end{array}$} \\
\hline & $l t$ & $\begin{array}{l}l t-F \\
l t-R\end{array}$ & $\begin{array}{l}\text { GGCGACAGATTATACCGTGC } \\
\text { CGGTCTCTATATTCCCTGTT }\end{array}$ & 450 & \\
\hline EIEC & ipaH & $\begin{array}{l}\text { ipaIII } \\
\text { ipaIV }\end{array}$ & $\begin{array}{l}\text { GTTCCTTGACCGCCTTTCCGATACCGTC } \\
\text { GCCGGTCAGCCACCCTCTGAGAGTAC }\end{array}$ & 619 & $\begin{array}{l}\text { Sethabutr et al. } \\
\text { (1993) }\end{array}$ \\
\hline EAEC & $\operatorname{agg} R^{* *}$ & $\begin{array}{l}\text { aggRks1 } \\
\text { aggRks2 }\end{array}$ & $\begin{array}{c}\text { GTATACACAAAAGAAGGAAGC } \\
\text { ACAGAATCGTCAGCATCAGC }\end{array}$ & 254 & $\begin{array}{l}\text { Ratchtrachenchai } \\
\text { et al. (1997) }\end{array}$ \\
\hline
\end{tabular}

* Both genes, stx and eae, must be present to characterize a strain as EHEC.

** Detection of aggR gene can be used to characterize typical EAEC.

\section{Determination of antimicrobial susceptibility}

Susceptibility of isolates to antimicrobial agents was defined by disk diffusion method, following the guidelines of Clinical and Standards Institute (CLSI), which recommend the use of plates containing Muller-Hinton Agar (BD Difco, USA) (CLSI, 2015). The plates were incubated for approximately $16-18 \mathrm{~h}$ at $35 \pm 2^{\circ} \mathrm{C}$. All isolates were examined for susceptibility to the following antimicrobial agents: amoxicillin-clavulanate - AMC $(20 / 10 \mu \mathrm{g})$, aztreonam - ATM $(30 \mu \mathrm{g})$, cefepime - CPM $(30 \mu \mathrm{g})$, ceftazidime - CAZ $(30 \mu \mathrm{g})$; ceftriaxone - CRO $(30 \mu \mathrm{g})$, cefotaxime - CTX $(30 \mu \mathrm{g})$, meropenem MER $(10 \mu \mathrm{g})$, imipenem - IPM $(10 \mu \mathrm{g})$, cefoxitin CFO $(30 \mu \mathrm{g})$, ampicillin - AMP $(10 \mu \mathrm{g})$, tetracycline - TET $(30 \mu \mathrm{g})$, doxycycline - DOX $(10 \mu \mathrm{g})$, ciprofloxacin - CIP $(5 \mu \mathrm{g})$, norfloxacin - NOR $(10 \mu \mathrm{g})$, levofloxacin - LVX $(5 \mu \mathrm{g})$, tobramycin - TOB $(10 \mu \mathrm{g})$, gentamicin - GEN $(10 \mu \mathrm{g})$, amikacin - AMI $(30 \mu \mathrm{g})$, streptomycin - EST $(10 \mu \mathrm{g})$, chloramphenicol - CLO $(30 \mu \mathrm{g})$, trimethoprim/sulfamethoxazole - SUT $(1.25 / 23.75 \mu \mathrm{g})$ and nitrofurantoin - NIT $(300 \mu \mathrm{g})$. Inhibition zone diameters of microbial growth were measured and interpreted according to the breakpoints recommended by CLSI (2018). Isolates reported with an intermediate resistance for certain antimicrobial agents were considered resistant for statistical purposes, since the use of such antibiotics are not advisable for clinical treatment. Escherichia coli ATCC 25922 strain was used as quality control to determine susceptibility to antimicrobial agents.

Phenotypic and genotypic characterization of isolates producing extended-spectrum betalactamases (ESBL)

Screening for ESBL-producing E. coli isolates was carried out by the disk diffusion test as 
recommended by CLSI (2018). To perform this test, one amoxicillin-clavulanate disk was placed in the center of a Mueller-Hinton agar plate, and at a distance of $30 \mathrm{~mm}$ from other beta-lactam disks (ceftazidime, cefotaxime, ceftriaxone, cefepime, and aztreonam). The plate was incubated for $24 \mathrm{~h}$ at $37^{\circ} \mathrm{C}$. After incubation, it was considered an indicative that a sample was ESBL-producer if there was an increase of the inhibition zone or the formation of a phantom zone, followed by distortion of the inhibition zone around the $\beta$-lactam disk (DRIEUX et al., 2008). The isolates that showed a phenotypic ESBL-producing profile were further investigated by multiplex PCR as described by Dallenne et al. (2010) with some modifications. One PCR approach was to detect the presence of the genes $b l a_{\mathrm{TEM}}, b l a_{\mathrm{SHV}}, b l a_{\mathrm{OXA}-1}$, whereas the other focused on the genes of groups $b l a_{\text {CTX-M-1 }}, b l a_{\text {CTX-М-2 }}$ e $b l a_{\text {СТХ-М-9 }}$ using the primers listed in table 2.

Table 2. List of primers used in PCR for detection of ESBL-producing E. coli isolates.

\begin{tabular}{|c|c|c|c|c|}
\hline$\beta$-lactamase & Primer & Sequence of oligonucleotides ( $\left.5^{\prime}-3^{\prime}\right)$ & $\begin{array}{c}\text { Size of } \\
\text { amplicon } \\
\text { (bp) }\end{array}$ & $\begin{array}{l}\text { Described } \\
\text { by: }\end{array}$ \\
\hline $\begin{array}{l}\text { bla }_{\mathrm{TEM}}(\mathrm{TEM} \text { variants in- } \\
\text { cluding } \text { bla }_{\mathrm{TEM}-1} \text { and bla } \\
\text { TEM-2}\end{array}$ & $\begin{array}{l}\text { MultiTSO-T_for } \\
\text { MultiTSO-T_rev }\end{array}$ & $\begin{array}{l}\text { CATTTCCGTGTCGCCCTTATTC } \\
\text { CGTTCATCCATAGTTGCCTGAC }\end{array}$ & 800 & \multirow{6}{*}{$\begin{array}{l}\text { Dallenne } \\
\text { et al. } \\
(2010)\end{array}$} \\
\hline $\begin{array}{l}b l a_{\mathrm{SHV}}(\mathrm{SHV} \text { variants in- } \\
\left.\text { cluding } b l a_{\mathrm{SHV}-1}\right)\end{array}$ & $\begin{array}{l}\text { MultiTSO-S_for } \\
\text { MultiTSO-S_rev }\end{array}$ & $\begin{array}{l}\text { AGCCGCTTGAGCAAATTAAAC } \\
\text { TCCCGCAGATAAATCACCAC }\end{array}$ & 713 & \\
\hline $\begin{array}{c}b l a_{\mathrm{OXA}}\left(b l a_{\mathrm{OXA}-1}, b l a_{\mathrm{OXA}-1} \text { and }\right. \\
\left.\quad b l a_{\mathrm{OXA}-30}\right)\end{array}$ & $\begin{array}{l}\text { MultiTSO-S_for } \\
\text { MultiTSO-S_rev }\end{array}$ & $\begin{array}{l}\text { GGCACCAGATTCAACTTTCAAG } \\
\text { GACCCCAAGTTTCCTGTAAGTG }\end{array}$ & 564 & \\
\hline $\begin{array}{l}b l a_{\text {СTX-M }} \text { group } 1\left(b l a_{\text {СТХ-M-1 }} \text {, }\right. \\
\left.b l a_{\text {СТХ-M-3 }} \text { and } b l a_{\text {СТХ-M-15 }}\right)\end{array}$ & $\begin{array}{l}\text { MultiCTXMGp1_f } \\
\text { MultiCTXMGp1-2r }\end{array}$ & $\begin{array}{l}\text { TAGGAARTGTGCCGCTGYA } \\
\text { CGATATCGTTGGTGGTRCCAT }\end{array}$ & 688 & \\
\hline$b l a_{\text {СТХ-M }}$ group $2\left(b l a_{\text {СТХ-М-2 }}\right)$ & $\begin{array}{l}\text { MultiCTXMGp2_f } \\
\text { MultiCTXMGp1-2r }\end{array}$ & $\begin{array}{l}\text { CGTTAACGGCACGATGAC } \\
\text { CGATATCGTTGGTGGTRCCAT }\end{array}$ & 404 & \\
\hline $\begin{array}{l}b l a_{\text {СТX-M }} \text { group } 9\left(b l a_{\text {СТX-M-9 }}\right. \\
\left.\quad \text { and } b l a_{\text {СТХ-M-14 }}\right)\end{array}$ & $\begin{array}{l}\text { MultiCTXMGp9_f } \\
\text { MultiCTXMGp9_r }\end{array}$ & $\begin{array}{l}\text { TCAAGCCTGCCGATCTGGT } \\
\text { TGATTCTCGCCGCTGAAG }\end{array}$ & 561 & \\
\hline
\end{tabular}

To detect these genes, PCR mix contained PCR buffer (Tris- $\mathrm{HCl}-20 \mathrm{mM}, \mathrm{KCl}-50 \mathrm{mM}$ ), $\mathrm{MgCl}_{2}(1.5 \mathrm{mM})$, dNTP $(200 \mathrm{mM}$ of each), primers (4 pmol of each) and bacterial DNA (15-60ng) to result in a final volume of $25 \mu \mathrm{L}$. Thermal cycling parameters for the genes $b l a_{\mathrm{TEM}}$ and $b l a_{\mathrm{SHV}}$ as well as for $b l a_{\text {СТХ-М1 }}, b l a_{\text {СТХ-М2 }}$ and $b l a_{\text {СТХ-М9 }}$ were as follows: initial denaturation step at $94^{\circ} \mathrm{C}$ for 10 min, followed by 40 cycles of $94^{\circ} \mathrm{C}$ for $40 \mathrm{~s}, 56^{\circ} \mathrm{C}$ for $40 \mathrm{~s}$ and $72^{\circ} \mathrm{C}$ for $1 \mathrm{~min}$, and a final extension at $72^{\circ} \mathrm{C}$ for $7 \mathrm{~min}$. Amplified fragments were separated electrophoretically $(100 \mathrm{~V}, 300 \mathrm{~mA})$ for $1 \mathrm{~h}$ using $2 \%$ agarose gel. Amplicons were stained with GelRed ${ }^{\mathrm{TM}}$ and visualized on transilluminator. Klebsiella pneumoniae CCBH5991 and Klebsiella pneumoniae CCBH15948 (both kindly donated by the Fundação Oswaldo Cruz - Fiocruz) were used as positive quality control to detect the genes $b l a_{\mathrm{TEM}^{+}}, b l a_{\mathrm{SHV}+}, b l a_{\mathrm{CTX}^{-\mathrm{M}^{+}}}$and $b l a_{\mathrm{OXA}^{+}}$. Escherichia coli ATCC 25922 reference strain was used as a negative control. 
Phenotypic and genotypic characterization of carbapenemase-producing isolates

The isolates that exhibited resistance or intermediate resistance to carbapenems were further investigated. We placed meropenem and imipenem disks on Mueller Hinton agar petri dishes (nonsupplemented) and, we also supplemented ones with EDTA, cloxacillin (CLOX) and phenylboronic acid (PhBA). Non-supplemented disks were used for comparison to supplemented disks. The interpretation consisted on checking if: a) isolates with an inhibition zone difference $\geq 5 \mathrm{~mm}$ for imipenem or meropenem supplemented with EDTA (compared to non-supplemented) were considered potential metallo-beta-lactamase (MBL); b) isolates with an inhibition zone difference $\geq 5 \mathrm{~mm}$ for carbapenem supplemented with phenylboronic acid in comparison to any substrate (imipenem or meropenem) were considered potential Klebsiella pneumoniae carbapenemase (KPC) producers; c) Inhibition zone difference $\geq 5 \mathrm{~mm}$ for antimicrobial disks supplemented with CLOXA and AFB (compared to non-supplemented substrate) were classified as plasmid-mediated AmpC; d) If zone difference $(<5 \mathrm{~mm})$ for non-supplemented and supplemented antimicrobial disks was observed, isolates were possibly considered producers of other $\beta$-lactamase (ex. OXA-48) or exhibited porin loss (ANVISA, 2013).

After phenotypic screening, PCR was carried out to detect the presence of the gene bla ${ }_{\text {OXA-48-LIKE }}$ using the following pair of primers: forward (5' GCTTGATCGCCCTCGATT 3') and reverse (5' GATTTGCTCCGTGGCCGAAA 3') (DALLENNE et al., 2010). Klebsiella pneumoniae CCBH23559 (Fundação Oswaldo Cruz - Fiocruz) and Escherichia coli ATCC 25922 reference strains was used as positive and negative quality control, respectively.

Evaluation of biofilm-production ability by Congo red agar

Biofilm formation of $E$. coli isolates was performed by the inoculation method in Congo red agar as described by Freeman et al. (1989). The isolates were cultivated into plates containing Congo red agar and incubated for $24 \mathrm{~h}$ at $37^{\circ} \mathrm{C}$ under aerobic conditions. Isolates considered biofilm producer formed black colonies with a dry crystalline consistency, while the non-biofilm producer ones formed red colonies with a smooth and darkened appearance in the center.

\section{Results and Discussion}

The virulence genes were identified in 25 out of the 117 studied isolates $(21.37 \%)$ and three pathotypes of E. coli were found. EPEC was the most prevalent pathotype, since 15 isolates (12.82\%) exhibited the presence of gene eae. ETEC was detected in 8 isolates $(6.84 \%)$ by the presence of of gene $s t$ and/or $l t$, while EAEC was identified in 2 isolates $(1.71 \%)$ that were positive for gene $a g g R$ (table 3 ). EAEC encondes genes that codify adhesin proteins, aggregative adherence factors, regulated by the expression of $a g g R$ gene. This transcriptional activator is responsible for the expression of plasmid-borne and chromosomal virulence factors. For this reason, detection of $a g g R$ gene can be used to characterize typical EAEC (BRÜSSOW, 2014; HARRIGTON et al., 2006).

These results were similar to several previous studies, like the one conducted by Holko et al. (2006). They found virulence gene in $9.47 \%$ of the $E$. coli isolates obtained from cheese produced by raw milk in Slovakia, being EPEC the most prevalent pathotype. Altalhi and Hassan (2009) detected the presence of gene eae, typically found in EPEC strains, in $9.1 \%$ of samples of raw milk and raw dairy products analyzed in Saudi Arabia. Further, Canizalez-Roman et al. (2013) investigated the frequency of diarrheagenic E. coli strains isolated in different types of food in Mexico, and among the analyzed dairy products, EPEC was the most prevalent $(9.1 \%)$ pathogenic type, whereas EAEC and ETEC were detected in $1.4 \%$ and $0.7 \%$ of 
strains, respectively. On the other hand, de Campos et al. (2018) detected only the presence of a single diarrheagenic E. coli isolate (2.56\%), characterized as EPEC, in different types of cheese produced with raw milk in Brazil. Ombarak et al. (2016) observed a high bacterial contamination rate of raw milk and raw cheese by potentially pathogenic $E$. coli isolates in Egypt due to the presence of virulence genes, being EPEC detected in only one sample $(0.90 \%)$.

Table 3. Profile of $E$. coli isolates from raw milk and serrano artisanal cheese that exhibited virulence genes.

\begin{tabular}{|c|c|c|c|c|c|c|}
\hline Isolate * & $\begin{array}{c}\text { E. coli } \\
\text { (pathotype) }\end{array}$ & $\begin{array}{l}\text { Virulence } \\
\text { gene }\end{array}$ & $\begin{array}{l}\text { Antimicrobial } \\
\text { resistance }\end{array}$ & $\begin{array}{l}\text { N. of resis- } \\
\text { tance classes }\end{array}$ & $\begin{array}{l}\text { Beta-lacta- } \\
\text { mase genes }\end{array}$ & Biofilm** \\
\hline $1 \mathrm{M}$ & EPEC & eae & - & - & - & - \\
\hline $2 \mathrm{M}$ & EPEC & eae & $\mathrm{AMC}, \mathrm{CFO}, \mathrm{AMP}$ & 1 & - & + \\
\hline $3 \mathrm{M}$ & EPEC & eae & EST & 1 & - & + \\
\hline $4 \mathrm{C}$ & EPEC & eae & AMP, TET, DOX, EST & 3 & - & - \\
\hline $5 \mathrm{C}$ & EPEC & eae & AMC, CFO, TET, DOX, EST & 3 & - & + \\
\hline $6 \mathrm{C}$ & EPEC & eae & TET, DOX, EST & 2 & - & + \\
\hline $7 \mathrm{C}$ & EPEC & eae & TET, DOX, EST & 2 & - & - \\
\hline $8 \mathrm{C}$ & EPEC & eae & GEN & 1 & - & + \\
\hline $9 \mathrm{C}$ & EPEC & eae & EST, NIT & 2 & - & + \\
\hline $10 \mathrm{C}$ & ETEC & st; lt & AMC, IPM, CFO, TET & 2 & - & + \\
\hline $11 \mathrm{C}$ & EPEC & eae & - & - & - & - \\
\hline $12 \mathrm{C}$ & ETEC & $s t$ & NIT & 1 & - & - \\
\hline $13 \mathrm{C}$ & EPEC & eae & - & - & - & + \\
\hline $14 \mathrm{C}$ & EPEC & eae & - & - & - & + \\
\hline $15 \mathrm{C}$ & ETEC & $s t$ & EST & 1 & - & + \\
\hline $16 \mathrm{C}$ & EAEC & $\operatorname{aggR}$ & CFO, EST & 2 & - & + \\
\hline $17 \mathrm{C}$ & ETEC & $s t ; l t$ & - & - & - & + \\
\hline $18 \mathrm{C}$ & ETEC & $s t ; l t$ & - & - & - & - \\
\hline $19 \mathrm{C}$ & EPEC & eae & - & - & - & + \\
\hline $20 \mathrm{C}$ & EAEC & $\operatorname{aggR}$ & AMP, TET, DOX, CIP, SUT & 4 & - & + \\
\hline $21 \mathrm{C}$ & ETEC & st & DOX, EST & 2 & - & - \\
\hline $22 \mathrm{C}$ & EPEC & eae & $\begin{array}{l}\text { AMC, ATM, CPM, CAZ, } \\
\text { CRO, CTX, CFO, AMP }\end{array}$ & 1 & $B l a_{\mathrm{TEM}}$ & + \\
\hline $23 \mathrm{C}$ & ETEC & st & - & - & - & - \\
\hline $24 \mathrm{C}$ & ETEC & st & - & - & - & + \\
\hline $25 \mathrm{C}$ & EPEC & eae & - & - & - & - \\
\hline
\end{tabular}

* M - Milk; C- Cheese. ** Congo red test: (-) negative; (+) positive.

The presence of EPEC, ETEC and EAEC in samples of raw milk and artisanal cheese points major flaws in hygienic and sanitary measures adopted by the producers, not only at the milk collection but also during the processing (manufacture) of cheese, since the isolation of these microorganisms is reported in a wide range of animals used for food production (HERNANDES et al., 2009), such as dairy cattle (MONAGHAN et al., 2013; TÓTH et al., 2009), and humans are considered 
the main hosts/reservoirs for these pathotypes (HU; TORRES, 2015; YANG; WANG, 2014). Such types of food could be directly or indirectly contaminated by faeces of humans and/or infected animals, which become carriers and promote transmission of diarrheagenic E. coli isolates to consumers. Consequently, the consumption of such products might result in foodborne illness, an important public health issues, since subclinical, severe or fatal infections could be caused/developed in children and adults (DUBREUIL, 2014; YANG; WANG, 2014).

The antimicrobial susceptibility profile of 117 E. coli isolates, using 23 antibiotics, was phenotypically defined by disk diffusion method. In general, 62 isolates (52.99\%) were considered susceptible to the tested antimicrobial agents. The results indicated that all isolates were susceptible to meropenem, norfloxacin, levofloxacin, tobramycin, amikacin and chloramphenicol (table 4). A total of 10 isolates $(8.55 \%)$, all originally from cheese samples, exhibited a multi-drug resistance profile, which means they were resistant to three or more antimicrobial classes. On the other hand, 21 isolates (17.95\%), two obtained from milk samples and the others from cheese, were resistant to two antimicrobial classes. These results were similar to the findings described by Guillén et al. (2014), which detected multiresistance in $11.1 \%$ of $E$. coli isolates obtained from artisanal dairy products manufactured in Venezuela. Ribeiro et al. (2016) and Ombarak et al. (2018) reported multiresistance rates lower than $20 \%$ in E. coli isolates collected from raw milk and/or cheese produced with raw milk in Brazil and Egypt, respectively. In contrast, de Campos et al. (2018) disclosed that 33.3\% of E. coli strains, originally isolated from raw milk cheese produced in Brazil, were resistant to at least one antimicrobial agent, and only a single isolate $(2.56 \%)$ was multidrug-resistant.

Table 4. Antimicrobial susceptibility profile of $E$. coli isolates recovered from raw milk and serrano artisanal cheese.

\begin{tabular}{lcccc}
\hline \multirow{2}{*}{ Antimicrobial agent } & \multicolumn{4}{c}{ Susceptibility profile n(\%)* } \\
\cline { 2 - 5 } & $\mathbf{R}$ & $\mathbf{I}$ & SDD & S \\
\hline Amoxacillin - clavulanate (AMC) & $16(13.68)$ & - & - & $101(86.32)$ \\
Aztreonam (ATM) & $3(2.56)$ & - & - & $114(97.44)$ \\
Cefepime (CPM) & $1(0.85)$ & - & $1(0.85)$ & $115(98.3)$ \\
Ceftazidime (CAZ) & $2(1.71)$ & $1(0.85)$ & - & $114(97.44)$ \\
Ceftriaxone (CRO) & $3(2.56)$ & $2(1.71)$ & - & $112(95.73)$ \\
Cefotaxime (CTX) & $3(2.56)$ & - & - & $114(97.44)$ \\
Meropenem (MER) & - & - & - & $117(100.00)$ \\
Imipenem (IPM) & - & $3(2.56)$ & - & $114(97.44)$ \\
Cefoxitin (CFO) & $16(13.68)$ & - & - & $101(86.32)$ \\
Ampicillin (AMP) & $20(17.10)$ & $9(7.69)$ & - & $88(75.21)$ \\
Tetracycline (TET) & $18(15.38)$ & $2(1.71)$ & - & $97(82.91)$ \\
Doxycycline (DOX) & $17(14.53)$ & $1(0.85)$ & - & $99(84.62)$ \\
Ciprofloxacin (CIP) & - & $1(0.85)$ & - & $116(99.15)$ \\
Norfloxacin (NOR) & - & - & - & $117(100.00)$ \\
Levofloxacin (LVX) & - & - & - & $117(100.00)$ \\
Tobramycin (TOB) & - & - & - & $117(100.00)$
\end{tabular}


continuation

Gentamicin (GEN)

Amikacin (AMI)

Streptomycin (EST)

Chloramphenicol (CLO)

Nitrofurantoin (NIT)

Trimethoprim-sulfamethoxazole (SUT)

$\begin{array}{cccc}- & 2(1.71) & - & 115(98.29) \\ - & - & - & 117(100.00) \\ 10(8.55) & 14(11.96) & - & 93(79.49) \\ - & - & - & 117(100.00) \\ 2(1.71) & 1(0.85) & - & 114(97.44) \\ 8(6.84) & 1(0.85) & - & 108(92.31)\end{array}$

* R - Resistant; I - Intermediate resistant; SDD - Susceptible dose-dependent; S - Susceptible.

On the subject of susceptibility profile of $25 E$. coli isolates potentially pathogenic (EPEC, ETEC and EAEC) found in this study, we observed: $11(44 \%)$ were resistant to two or more tested antimicrobial agents, six (24\%) were resistant to two antimicrobial classes $(6 \mathrm{C}, 7 \mathrm{C}, 9 \mathrm{C}, 10 \mathrm{C}, 16 \mathrm{C}$, $21 \mathrm{C})$, and three isolates (12\%) were multi-drug resistant (4C, 5C and 20C) (table 3). Our results showed consistency with those presented by Canizalez-Roman et al. (2013), which demonstrated that $39.2 \%$ of diarrheagenic E. coli strains isolated in food items manufactured in Mexico, including dairy products, were resistant to two or more antibiotics. In addition, Wang et al. (2017) verified that $61 \%$ of diarrheagenic $E$. coli isolates, recovered from different types of food commercialized in local Japanese retail markets, were resistant to at least one of the test antimicrobial agents, and 70\% of them were resistant to two or more antibiotics. Moreover, Gómez-Aldapa et al. (2016) recently detected multiresistance in all diarrheagenic isolates recovered from coriander samples in Mexico.

Transmission of virulence genes and resistance by $E$. coli to other intestinal pathogenic bacteria is often plasmid-associated. Therefore, industrialized food and animal source food are potential reservoirs for antimicrobial resistant and virulent bacteria (KIRBIS; KRIZMAN, 2015). Since we recovered pathogenic antibiotic-resistant $E$. coli isolates from raw milk and serrano artisanal cheese, it is of utmost importance to point out questions related to food safety regulations, regarding aspects of quality raw material, primary production, processing, retailing and consumer-handling, as well as education in hygienic handling of food for individuals involved in the manufacturing process.

An investigation of ESBL-producing isolates was also carried out, and we found out that four $(3.42 \%)$ samples, one from milk and the others from cheese, were positive for ESBL phenotype and harbored the $b l a_{\text {TEM }}$ gene. One isolate showed multiresistance profile (C); whereas another one (D), characterized as EPEC, exhibited resistance to $80 \%$ of the tested $\beta$-lactams (table 5). Likewise, studies worldwide also reported the presence of ESBL-producing $E$. coli isolates in raw milk and/or cheese manufactured in Turkey (TEKINER; OZPINAR, 2016; TEPELI; ZORBA, 2018), Egypt (OMBARAK et al., 2018), Czech Republic (SKOČKOVÁ et al., 2015), Brazil (RIBEIRO et al., 2016) and Slovakia (VRABEC et al., 2015), being the $b l a_{\text {TEM }}$ gene the most prevalent among the recovered samples. ESBL-producing microorganisms represent a serious global health concern because they are frequently isolated (BOUCHILLON et al., 2004), and the group of $\beta$-lactams is still the most commonly worldwide used antimicrobial agent against Gram-negative bacterial infections (OCA et al., 2015), which lately leads to complicated treatment strategies. 
Table 5. Profile of ESBL-producing E. coli isolated from raw milk and serrano artisanal cheese.

\begin{tabular}{cccc}
\hline Isolate $^{*}$ & Beta-lactamase (gene) & Antimicrobial resistance & E. coli (Pathotype) \\
\hline $\mathrm{A}(\mathrm{M})$ & $b l a_{\mathrm{TEM}}$ & $\mathrm{ATM}, \mathrm{CAZ}, \mathrm{CRO}, \mathrm{CTX}, \mathrm{EST}$ & - \\
$\mathrm{B}(\mathrm{C})$ & $b l a_{\mathrm{TEM}}$ & $\mathrm{CRO}, \mathrm{AMP}$ & - \\
$\mathrm{C}(\mathrm{C})$ & $b l a_{\mathrm{TEM}}$ & $\mathrm{CAZ}, \mathrm{CTX}, \mathrm{TET}, \mathrm{DOX}, \mathrm{EST}$ & - \\
$\mathrm{D}(\mathrm{C})$ & $b l a_{\mathrm{TEM}}$ & $\mathrm{AMC}, \mathrm{ATM}, \mathrm{CPM}, \mathrm{CAZ}, \mathrm{CRO}, \mathrm{CTX}, \mathrm{CFO}, \mathrm{AMP}$ & EPEC \\
\hline
\end{tabular}

* (M) - Milk; (C) - Cheese. ** Amoxacillin - clavulanate (AMC); Ampicillin (AMP); Aztreonam (ATM); Cefepime (CPM); Cefotaxime (CTX); Cefoxitin (CFO); Ceftazidime (CAZ); Ceftriaxone (CRO); Doxycycline (DOX); Streptomycin (EST); Tetracycline (TET).

Since three isolates showed intermediate resistance to imipenem, a phenotypic screening of carbapenemase-producing E. coli was performed. However, all isolates were negative for this resistance profile. Based on this result, we carried out PCRs to detect the presence of OXA-48 gene, but none of the mentioned isolates were positive for it. In this case, intermediate resistance might be due to apparent loss or reduction in the expression level of porins present in these isolates (ANVISA, 2013).

Additionally, we verified the ability of $E$. coli isolates to potential form biofilm by the Congo red method. More than half of E. coli isolates $(67.52 \%$ out of 117 isolates) were considered potential biofilm producers. It is important to mention that there are other well-established methods to define and quantify biofilm-producer strains (AZEREDO et al., 2017). However, previous studies have demonstrated that Congo red agar method results well-correlated with the ones obtained by tissue culture plate and tube methods (PONNUSAMY et al., 2012) and by microtiter plate method (CHAGAS et al., 2017). For this reason, this method could be further performed in order to investigate the potential ability of $E$. coli isolates to form biofilm.

Out of the 79 isolates positive for Congo red agar test, $42(53.16 \%)$ were resistant to at least one of the tested antimicrobial agents. The biofilm formation profile of diarrheagenic $E$. coli isolates is shown in table 3 and revealed that $75 \%$ of them were considered potential biofilm-producers and resistant to at least one antibiotic. Analyses of the ten multi-drug resistant isolates found in the current study revealed that eight $(80 \%)$ were considered potential biofilm-producers. This finding is in line with the results obtained by Ponnusamy et al. (2012), emphasizing a possible association between these factors.

Biofilm formation in food processing environments depends on several factors, and dairy products are very susceptible to contamination especially due to unsuitable hygiene of machines and utensils (SREY et al., 2013). Biofilms are microbial communities embedded in an extracellular matrix composed mainly by polysaccharides and proteins adhered to the surface, and they remarkable underpin bacteria against effects of antibacterial treatments (COSTERTON et al, 1987; HOBLEY et al., 2015). This fact emphasizes even more the demand for actions to improve serrano artisanal cheese manufacturing processes in order to guarantee the quality of these foodstuffs for consumers.

\section{Conclusions}

This study reveals the presence of diarrheagenic E. coli isolates (EPEC, ETEC and EAEC) recovered from raw milk and artisanal cheese produced in Santa Catarina, South region of Brazil. We identified isolates that exhibited multi-drug resistance and ESBL-producing profiles, and the potential ability to form biofilms. These results warn of a serious public health issue, since these contaminated foods offer risks to consumers' health. For that reason, 
they underpin the need to intensify hygienicsanitary controls in all steps of production, and also to implement measures that allow epidemiological control of potential pathogenic bacterial strains in artisanal cheese produced in the Serrana region of Santa Catarina, South of Brazil.

\section{Acknowledgements}

We thank the Fundação Oswaldo Cruz (Fiocruz) and the Instituto Adolfo Lutz for providing the reference strains.

\section{References}

AGÊNCIANACIONAL DE VIGILÂNCIA SANITÁRIA - ANVISA. Medidas de prevenção e controle de infecções por enterobactérias multirresistentes. Brasília: Anvisa, 2013. (Nota técnica n. 01/2013).

ALTALHI, A. D.; HASSAN, S. A. Bacterial quality of raw milk investigated by Escherichia coli and isolates analysis for specific virulence-gene markers. Food Control, Guildford, v. 20, n. 10, p. 913-917, 2009.

AZEREDO, J.; AZEREDO, N. F.; BRIANDET, R.; CERCA, N.; COENYE, T.; COSTA, A. R.; DESVAUX, M.; BONAVENTURA, G.; HÉBRAUD, M.; JAGLIC, Z.; KAČÁNIOVÁ, M.; KNØCHEL, S.; LOURENÇO, A.; MERGULHÃO, F.; MEYER, R. L.; NYCHAS, G.; SIMÕES, M.; TRESSE, O.; STERNBERG, C. Critical review on biofilm methods. Critical Reviews in Microbiology, London, v. 43, n. 3, p. 313-351, 2017.

BEUTIN, L.; MARTIN, A. Outbreak of shiga toxinproducing Escherichia coli (STEC) O104:H4 infection in Germany causes a paradigm shift with regard to human pathogenicity of STEC strains. Journal of Food Protection, Ames, v. 75, n. 2, p. 408-418, 2012.

BOUCHILLON, S. K.; JOHNSON, B. M.; HOBAN, D. J.; JOHNSON, J. L.; DOWZICKY, M. J.; WU, D. H.; VISALLI, M. A.; BRADFORD, P. A. Determining incidence of extended spectrum beta-lactamase producing Enterobacteriaceae, vancomycin-resistant Enterococcus faecium and methicillin-resistant Staphylococcus aureus in 38 centres from 17 countries: the PEARLS study 20012002. International Journal of Antimicrobial Agents, London, v. 24, n. 2, p. 119-124, 2004.

BRÜSSOW, H. Enteroaggregative E. coli. Encyclopedia of Food Microbiology, Oxford, v. 1, n. 1, p. 706-712, 2014.
BUSH, K.; JACOBY, G. A. Updated functional classification of $\beta$-Lactamases. Antimicrobial Agents and Chemotherapy, Bethesda, v. 54, n. 3, p. 969-976, 2010.

CAMPOS, A. C. L. P. de; PUÑO-SARMIENTO, J. J.; MEDEIROS, L. P.; GAZAL, L. E. S.; MALUTA, R. P.; NAVARRO, A.; KOBAYASHI, R. K. T.; FAGAN, E. P.; NAKAZATO, G. Virulence genes and antimicrobial resistance in Escherichia coli from cheese made from unpasteurized milk in Brazil. Foodborne Pathogens and Disease, New York, v. 15, n. 2, p. 94-100, 2018.

CANIZALEZ-ROMAN, A.; GONZALEZ-NUÑEZ, E.; VIDAL, J. E.; FLORES-VILLASEÑOR, H.; LEÓN-SICAIROS, N. Prevalence and antibiotic resistance profiles of diarrheagenic Escherichia coli strains isolated from food items in northwestern Mexico. International Journal of Food Microbiology, Amsterdam, v. 164, n. 1, p. 36-45, 2013.

CARATTOLI, A. Plasmids and the spread of resistance. International Journal of Medical Microbiology, Jena, v. 303, n. 6, p. 298-304, 2013.

CHAGAS, L. G. S.; MELO, P. C.; BRASÃO, S. C.; SILVESTRE, G. B. R.; GUIMARÃES, E. C.; LIMA, A. M. C. Evaluation of biofilm formation by bacterial strains isolated from milking equipment and milk samples from cows with mastitis. Semina: Ciências Agrárias, Londrina, v. 38, n. 4, p. 1887-1896, 2017.

CLINICAL AND LABORATORY STANDARDS INSTITUTE - CLSI. Performance standards for antimicrobial disk susceptibility tests. Approved standard-12 ${ }^{\text {th }}$ ed. M02-A12. Wayne: CLSI, 2015.

- Performance standards for antimicrobial susceptibility testing. Approved standard-28 ${ }^{\text {th }}$ ed. M100-S28. Wayne: CLSI, 2018.

COSTERTON, J. W.; CHENG, K. J.; GEESEY, G. G.; LADD, T. I.; NICKEL, J. C.; DASGUPTA, M.; MARRIE, T. J. Bacterial biofilms in nature and disease. Annual Review of Microbiology, California, v. 41, n. 1, p. 435-464, 1987.

CROXEN, M.; LAW, R.; SCHOLZ, R.; KEENEY, K.; WLODARSKA, M.; FINLAY, B. Recent advances in understanding enteric pathogenic Escherichia coli. Clinical Microbiology Reviews, Washington, v. 26, n. 4, p. 823-880, 2013.

CULLER, H. F.; MOTA, C. M.; ABE, C. M.; ELIAS, W. P.; SIRCILI, M. P.; FRANZOLIN, M. R. Atypical enteropathogenic Escherichia coli strains form biofilm on abiotic surfaces regardless of their adherence pattern on cultured epithelial cells. BioMed Research International, London, v. 2014, n. article 845147, p. 1-10, 2014. 
DALLENNE, C.; COSTA, A. da; DECRÉ, D.; FAVIER, C.; ARLET, G. Development of a set of multiplex PCR assays for the detection of genes encoding important $\beta$-lactamases in Enterobacteriaceae. Journal of Antimicrobial Chemotherapy, London, v. 65, n. 3, p. 490-495, 2010.

DALMINA, K. Avaliação do período mínimo de maturação para comercialização do queijo artesanal serrano de Santa Catarina. 2018. Dissertação (Mestrado em Ciência Animal) - Centro de Ciências Agroveterinárias, Universidade do Estado de Santa Catarina, Santa Catarina.

DOYLE, J. J.; DOYLE, J. L. A rapid DNA isolation procedure for small quantities of fresh leaf tissue. Phytochemical Bulletin, Irvine, v. 19, n. 1, p. 11-15, 1987.

DRIEUX, L.; BROSSIER, F.; SOUGAKOFF, W.; JARLIER, V. Phenotypic detection of extended-spectrum $\beta$-lactamase production in Enterobacteriaceae: review and bench guide. Clinical Microbiology and Infection, Oxford, v. 14, p. 90-103, 2008. Supplement 1.

DUBREUIL, J. D. Enterotoxigenic E. coli (ETEC). Encyclopedia of Food Microbiology, Oxford, v. 2, n. 1, p. 728-734, 2014.

EUROPEAN CENTRE FOR DISEASE PREVENTION AND CONTROL - ECDC. Antimicrobial resistance surveillance in Europe 2012. Annual report of the European antimicrobial resistance surveillance network (EARS-net). Stockholm: ECDC, 2013.

FREEMAN, D. J.; FALKINER, F. R.; KEANE, C. T. New method for detecting slime production by coagulase negative staphylococci. Journal of Clinical Pathology, London, v. 42, n. 8, p. 872-874, 1989.

GENC, O.; AKSU, E.; GULCAN, A. The identification of carbapenemase types in Enterobacteriaceae by using molecular assay and phenotyping confirmation tests. Journal of Microbiological Methods, Amsterdam, v. 125, n. 1, p. 8-11, 2016.

GIRÃO, D. M.; GIRÃO, V. B. C.; IRINO, K.; GOMES, T. A. T. Classifying Escherichia coli. Emerging Infectious Diseases, Atlanta, v. 12, n. 8, p. 1297-1299, 2006.

GÓMEZ-ALDAPA， C. A.; SEGOVIA-CRUZ, J. A.; CERNA-CORTES, J. F.; RANGEL-VARGAS, E.; SALAS-RANGEL, L. P.; GUTIÉRREZALCÁNTARA, E. J.; CASTRO-ROSAS, J. Prevalence and behavior of multidrug-resistant Shiga toxinproducing Escherichia coli, enteropathogenic E. coli and enterotoxigenic E. coli on coriander. Food Microbiology, London, v. 59, n. 1, p. 97-113, 2016.

GUILlÉN, L.; MILlÁN, B.; ARAQUE, M. Caracterización molecular de cepas de Escherichia coli aisladas de produtos lácteos artesanales elaborados en Mérida, Venezuela. Infectio, Bogotá, v. 18, n. 3, p. 100$108,2014$.

GUNDOGAN, N.; AVCI, E. Prevalence and antibiotic resistance of extended spectrum beta-lactamase (ESBL) producing Escherichia coli and Klebsiella species isolated from foods of animal origin in Turkey. African Journal of Microbiology Research, Ibadan, v. 7, n. 31, p. 4059-4064, 2013.

GYLES, C. L.; FAIRBROTHER, J. M. Escherichia coli. In: GYLES, C. A.; PRESCOTT, J. F.; SONGER, J. G.; THOEN, C. O. Pathogenesis of bacterial infections in animals. $4^{\text {th }}$ ed. Iowa: Wiley-Blackwell, 2010. p. 231265.

HARRIGTON, S. M.; DUDLEY, E. G.; NATARO, J. P. Pathogenesis of enteroaggregative Escherichia coli infection. FEMS Microbiology Letters, Amsterdam, v. 254, n. 1, p. 12-18, 2006.

HERNANDES, R. T.; ELIAS, W. P.; VIEIRA, M. A. M.; GOMES, T. A. T. An overview of atypical enteropathogenic Escherichia coli. FEMS Microbiology Letters, Amsterdam, v. 297, n. 2, p. 137-149, 2009.

HOBLEY, L.; HARKINS, C.; MACPHEE, C. E.; STANLEY-WALL, N. R. Giving structure to the biofilm matrix: an overview of individual strategies and emerging common themes. FEMS Microbiology Reviews, Amsterdam, v. 39, n. 5, p. 649-669, 2015.

HOLKO, I.; BISOVA, T.; HOLKOVA, Z.; KMET, V. Virulence markers of Escherichia coli strains isolated from traditional cheeses made from unpasteurized sheep milk in Slovakia. Food Control, Guildford, v. 17, n. 5, p. 393-396, 2006.

HU, J.; TORRES, A. G. Enteropathogenic Escherichia coli: foe or innocent bystander? Clinical Microbiology and Infection, Oxford, v. 21, n. 8, p. 729-734, 2105.

KIRBIS, A.; KRIZMAN, M. Spread of antibiotic resistant bacteria from food of animal origin to humans and vice versa. Procedia Food Science, Amsterdam, v. 5, n. 1, p. 148-151, 2015.

KRAGH, K. N.; HUTCHISON, J. B.; MELAUGH, G.; RODESNEY, C.; ROBERTS, A. E. L.; IRIE, Y.; JENSEN, P. Ø.; DIGGLE, S. P.; ALLEN, R. J.; GORDON, V.; BJARNSHOLT, T. Role of multicellular aggregates in biofilm formation. mBio, Washington, v. 7 , n. 2, p. 1-11, 2016.

LEE, J. H.; BAE, I. K.; LEE, S. H. New definitions of extended-spectrum beta-lactamase conferring worldwide emerging antibiotic resistance. Medicinal Research Reviews, New York, v. 32, n. 1, p. 216-232, 2012. 
LÓPEZ-SAUCEDO, C.; CERNA, J. F.; VILLEGASSEPULVEDA, N.; THOMPSON, R.; VELAZQUEZ, F. R.; TORRES, J.; TARR, P. I.; ESTRADA-GARCÍA, T. Single multiplex polymerase chain reaction to detect diverse loci associated with diarrheagenic Escherichia coli. Emerging Infectious Diseases, Atlanta, v. 9, n. 1, p. 127-131, 2003.

MELO, F. D.; DALMINA, K. A.; PEREIRA, M. N.; RAMELLA, M. V.; THALER NETO, A.; VAZ, E. K.; FERRAZ, S. M. Avaliação da inocuidade e qualidade microbiológica do queijo artesanal serrano e sua relação com as variáveis físico químicas e o período de maturação. Acta Scientiae Veterinariae, Porto Alegre, v. 41, n. 1152, p. 1-7, 2013.

MONAGHAN, A.; BYRNE, B.; FANNING, S.; SWEENEY, T.; MCDOWELL, D.; BOLTON, D. J. Serotypes and virulence profiles of atypical enteropathogenic Escherichia coli (EPEC) isolated from bovine farms and abattoirs. Journal of Applied Microbiology, Oxford, v. 114, n. 2, p. 595-603, 2013.

NATARO, J. P.; KAPER, J. B. Diarrheogenic Escherichia coli. Clinical Microbiology Review, Washington, v. 11, n. 1, p. 142-201, 1998.

NOBILI, G.; FRANCONIERI, I.; BASANISI, M. G.; LA BELLA, G.; TOZZOLI, R.; CAPRIOLI, A.; LA SALANDRA, G. Isolation of Shiga toxin-producing Escherichia coli in raw milk and mozzarella cheese in southern Italy. Journal of Dairy Science, Champaign, v. 99, n. 10, p. 7877-7880, 2016.

NORDMANN, P.; GNIADKOWSKI, M.; GISKE, C. G.; POIREL, L.; WOODFORD, N.; MIRIAGOU, V.; European Network on Carbapenemases. Identification and screening of carbapenemase producing Enterobacteriaceae. Clinical Microbiology and Infection, Oxford, v. 18, n. 5, p. 432-438, 2012.

NORDMANN, P.; NAAS, T.; POIREL, L. Global spread of carbapenemase-producing Enterobacteriaceae. Emerging Infectious Diseases, Atlanta, v. 17, n. 10, p. 1791-1798, 2011.

NTUli, V.; NJAGE, P. M. K.; BUYS, E. M. Characterization of Escherichia coli and other Enterobacteriaceae in producer-distributor bulk milk. Journal of Dairy Science, Champaign, v. 99, n. 12, p. 9534-9549, 2016.

OCA, S. A. M. de; TALAVERA-ROJAS, M.; SORIANO-VARGAS, E.; BARBA-LEÓN, J.; VAZQUEZ-NAVARRETE, J. Determination of extended spectrum $\beta$-lactamases/AmpC $\beta$-lactamases and plasmid-mediated quinolone resistance in Escherichia coli isolates obtained from bovine carcasses in Mexico.
Tropical Animal Health and Production, Edinburgh, v. 47, n. 5, p. 975-981, 2015.

OMBARAK, R. A.; HINENOYA, A.; AWASTHI, S. P.; IGUCHI, A.; SHIMA, A.; ELBAGORY, A. R. M.; YAMASAKI, S. Prevalence and pathogenic potential of Escherichia coli isolates from raw milk and raw milk cheese in Egypt. International Journal of Food Microbiology, Amsterdam, v. 221, n. 1, p. 69-76, 2016.

OMBARAK, R. A.; HINENOYA, A.; ELBAGORY, A. M.; YAMASAKI, S. Prevalence and molecular characterization of antimicrobial resistance in Escherichia coli isolated from raw milk and raw milk cheese in Egypt. Journal of Food Protection, Ames, v. 81, n. 2, p. 226-232, 2018.

OSWALD, E.; SCHMIDT, H.; MORABITO, S.; KARCH, H.; MARCHÈS, O.; CAPRIOLI, A. Typing of intimin genes in human and animal enterohemorrhagic and enteropathogenic Escherichia coli: characterization of a new intimin variant. Infection and Immunity, Washington, v. 68, n. 1, p. 64-71, 2000.

PATERSON, D. L.; BONOMO, R. A. Extendedspectrum-lactamases: a clinical update. Clinical Microbiology Reviews, Washington, v. 18, n. 4, p. 657686, 2005.

PEREIRA, B. P.; VIEIRA, T. R.; VALENT, J. Z.; BRUZZA, A.; WAGNER, S. A.; PINTO, A. T.; SCHMIDT, V. Implicações do processo produtivo na qualidade do queijo artesanal serrano. Revista Eletrônica em Gestão, Educação e Tecnologia Ambiental, Santa Maria, v. 18, p. 116-126, 2014. Edição Especial.

PFEIFER, Y.; CULLIK, A.; WITTE, W. Resistance to cephalosporins and carbapenems in Gram-negative bacterial pathogens. International Journal of Medical Microbiology, Jena, v. 300, n. 6, p. 371-379, 2010.

PONNUSAMY, P.; NATARAJAN, V.; SEVANAN, M. In vitro biofilm formation by uropathogenic Escherichia coli and their antimicrobial susceptibility pattern. Asian Pacific Journal of Tropical Medicine, Mumbai, v. 5, n. 3, p. 210-213, 2012.

PONTAROLO, G. H.; MELO, F. D.; MARTINI, C. L.; WILDEMANN, P.; ALESSIO, D. R. M.; SFACIOTTE, R. A. P.; THALER NETO, A.; VAZ, E. K.; FERRAZ, S. M. Quality and safety of artisan cheese produced in the Serrana region of Santa Catarina. Semina: Ciências Agrárias, Londrina, v. 38, n. 2, p. 739-748, 2017.

RANJBAR, R.; DEHKORDI, F. S.; SHAHREZA, M. H. S.; RAHIMI, E. Prevalence, identification of virulence factors, O-serogroups and antibiotic resistance properties of Shiga-toxin producing Escherichia coli strains isolated from raw milk and traditional dairy products. 
Antimicrobial Resistance and Infection Control, New York, v. 7, n. 53, p. 1-11, 2018.

RATCHTRACHENCHAI, O. A.; SUBPASU, S.; ITO, $\mathrm{K}$. Investigation on enteroaggregative Escherichia coli infection by multiplex PCR. Bulletin of the Department of Medical Sciences, Nonthaburi, v. 39, n. 1, p. 211-220, 1997.

RIBEIRO, L. F.; BARBOSA, M. M.; PINTO, F. R.; MALUTA, R. P.; OLIVEIRA, M. C.; SOUZA, V. de; MEDEIROS, M. I. de; BORGES, L. A.; AMARAL, L. A. do; FAIBROTHER, J. M. Antimicrobial resistance and virulence factors of Escherichia coli in cheese made from unpasteurized milk in three cities in Brazil. Foodborne Pathogens and Disease, New York, v. 13, n. 9, p. 469-476, 2016.

SETHABUTR, O; VENKATESAN, M.; MURPHY, G. S.; EAMPOKALAP, B.; HOGE, C. W.; ECHEVERRIA, P. Detection of Shigellae and enteroinvasive Escherichia coli by amplification of the invasion plasmid antigen H DNA sequence in patients with dysentery. Journal of Infectious Diseases, Chicago, v. 167, n. 2, p. 458-461, 1993.

SILAGYI, K.; KIM, S. H.; LO, Y. M.; WEI, C. I. Production of biofilm and quorum sensing by Escherichia coli $\mathrm{O} 157: \mathrm{H7}$ and its transfer from contact surfaces to meat, poultry, ready-to-eat deli, and produce products. Food Microbiology, London, v. 26, n. 5, p. 514-519, 2009.

SINGH, A. S.; LEKSHMI, M.; NAYAK, B. B.; KUMAR, S. H. Isolation of Escherichia coli harboring blaNDM-5 from fresh fish in India. Journal of Microbiology, Immunology and Infection, Oxford, v. 49, n. 5, p. 822823, 2016.

SKOČKOVÁ, A.; BOGDANOVIČOÁ, K.; KOLÁČKOVÁ, I.; KARPÍŠKOVÁ, R. Antimicrobialresistant and extended-spectrum $\beta$-lactamase-producing Escherichia coli in raw cow's milk. Journal of Food Protection, Ames, v. 78, n. 1, p. 72-77, 2015.

SLAMA, K. B.; JOUINI, A.; SALLEM, R. B.; SOMALO, S.; SÁENZ, Y.; ESTEPA, V.; BOUDABOUS, A.; TORRES, C. Prevalence of broadspectrum cephalosporin-resistant Escherichia coli isolates in food samples in Tunisia, and characterization of integrons and antimicrobial resistance mechanisms implicated. International Journal of Food Microbiology, Amsterdam, v. 137, n. 2, p. 281-286, 2010.

SOUZA, C. F. V.; DALlA ROSA, T.; AYUB, M. A. $Z$. Changes in the microbiological and physicochemical characteristics of Serrano cheese during manufacture and ripening. Brazilian Journal of Microbiology, São Paulo,
V. 34, n. 3, p. 260-266, 2003.

SPELlBERG, B.; BLASER, M.; GUIDOS, R. J.; BOUCHER, H. W.; BRADLEY, J. S.; EISENSTEIN, B. I.; GERDING, D.; LYNFIELD, R.; RELLER, L. B.; REX, J.; SCHWARTZ, D.; SEPTIMUS, E.; TENOVER, F. C.; GILBERT, D. N. Combating antimicrobial resistance: policy recommendations to save lives. Clinical Infectious Diseases, Chicago, v. 52, n. 5, p. S397-S428, 2011.

SREY, S.; JAHID, I. K.; HA, S. Biofilm formation in food industries: a food safety concern. Food Control, Guildford, v. 31, n. 2, p. 572-585, 2013.

SU, Y.; YU, C. Y.; TSAI, Y.; WANG, S. H.; LEE, C.; CHU, C. Fluoroquinolone-resistant and extended-spectrum b-lactamase-producing Escherichia coli from the milk of cows with clinical mastitis in Southern Taiwan. Journal of Microbiology, Immunology and Infection, Oxford, v. 49, n. 6, p. 892-901, 2016.

TEKINER, I. H.; OZPINAR, H. Occurrence and characteristics of extended spectrum beta-lactamasesproducing Enterobacteriaceae from foods of animal origin. Brazilian Journal of Microbiology, São Paulo, v. 47, n. 2, p. 444-451, 2016.

TEPELI, S. O.; ZORBA, N. N. D. Frequency of extendedspectrum $\beta$-lactamase (ESBL) - and AmpC $\beta$-lactamaseproducing Enterobacteriaceae in a cheese production process. Journal of Dairy Science, Champaign, v. 101, n. 4, p. 1-9, 2018.

THOMSON, K. S. Extended-spectrum $\beta$-lactamase, $\mathrm{AmpC}$, and carbapenemase issues. Journal of Clinical Microbiology, Washington, v. 48, n. 4, p. 1019-1025, 2010 .

Toma, C.; Lu, Y.; Higa, N.; Nakasone, N.; Chinen, I.; Baschkier, A.; Rivas, M.; Iwanaga, M. Multiplex PCR assay for identification of human diarrheagenic Escherichia coli. Journal of Clinical Microbiology, Washington, v. 41, n. 6, p. 2669-2671, 2003.

TÓTH, I.; SCHMIDT, H.; KARDOS, G.; LANCZ, Z.; CREUZBURG, K.; DAMJANOVA, I.; PÁSZTI, J.; BEUTIN, L.; NAGY, B. Virulence genes and molecular typing of different groups of Escherichia coli 0157 strains in cattle. Applied and Environmental Microbiology, Washington, v. 75, n. 19, p. 6282-6291, 2009.

TZOUVELEKIS, L. S.; MARKOGIANNAKIS, A.; PSICHOGIOU, M.; TASSIOS, P. T.; DAIKOS, G. L. Carbapenemases in Klebsiella pneumoniae and other Enterobacteriaceae: an evolving crisis of global dimensions. Clinical Microbiology Reviews, Washington, v. 25, n. 4, p. 682-707, 2012. 
VRABEC, M.; LOVAYOVÁ, V.; DUDRIKOVÁ, K.; GALLO, J.; DUDRIKOVÁ, E. Antibiotic resistance and prevalence of Enterococcus spp. and Escherichia coli isolated from Bryndza cheese. Italian Journal of Animal Science, Bologna, v. 14, n. 4, p. 609-614, 2015.

WANG, L.; NAKAMURA, H.; KAGE-NAKADAI, E.; HARA-KUDO, Y.; NISHIKAWA, Y. Prevalence, antimicrobial resistance and multiple-locus variablenumber tandem-repeat analysis profiles of diarrheagenic Escherichia coli isolated from different retail foods. International Journal of Food Microbiology, Amsterdam, v. 249, n. 1, p. 44-52, 2017.

WOODFORD, N.; TURTON, J. F.; LIVERMORE, D. M. Multiresistant gram-negative bacteria: the role of high-risk clones in the dissemination of antibiotic resistance. FEMS Microbiology Reviews, Amsterdam, v. 35, n. 5, p. 736-755, 2011.

YAMASAKI, S.; LIN, Z.; SHIRAI, H.; TERAI, A.; OKU, Y.; ITO, H.; OHMURA, M.; KARASAWA, T.;
TSUKAMOTO, T.; KURAZONO, H.; TAKEDA, Y. Typing of verotoxins by DNA colony hybridization with poly- and oligonucleotide probes, a bead-enzyme-linked immunosorbent assay, and polymerase chain reaction. Microbiology and Immunology, Tokyo, v. 40, n. 5, p. 345-352, 1996.

YANG, X.; WANG, H. Escherichia coli: pathogenic E. coli (introduction). Encyclopedia of Food Microbiology, Oxford, v. 2, n. 1, p. 695-701, 2014.

ZAFFARI, C. B.; MELLO, J. F.; COSTA, M. Qualidade bacteriológica de queijos artesanais comercializados em estradas do litoral norte do Rio Grande do Sul, Brasil. Ciência Rural, Santa Maria, v. 37, n. 3, p. 862-867, 2007.

ZURFLUH, K.; POIREL, L.; NORDMANN, P.; KLUMPP, J.; STEPHAN, R. First detection of Klebsiella variicola producing OXA-181 carbapenemase in fresh vegetable imported from Asia to Switzerland. Antimicrobial Resistance and Infection Control, London, v. 4, n. 38, p. 1-3, 2015. 